\title{
Implementation of Citizenship Education Teaching Materials Development in Increasing the Effectiveness of Online Learning During the Covid-19 Pandemic
}

\author{
Dara Aprilla ${ }^{1, *}$ Kokom Komalasari ${ }^{2}$ \\ ${ }^{1,2}$ Universitas Pendidikan Indonesia, Bandung, Indonesia \\ "Corresponding author.Email: daraaprilla@upi.edu
}

\begin{abstract}
Teaching materials are an important aspect in the learning process, because the teaching materials used are a source of knowledge that students accept. The problems that occur during online learning due to the Covid-19 pandemic make teachers need to innovate in choosing and using teaching materials so that students are able to develop cognitive, affective and psychomotor abilities. This study used a qualitative approach with a case study method, where the research was carried out at 18 Senior High School of Bandung City and 15 State Vocational High School of Bandung City the data collection techniques used interviews, observation and documentation, and data analysis used reduction, presentation and conclusion. The results showed that the implementation of the teaching materials used by the teacher was adjusted to the learning objectives of citizenship education and the needs of students, there were innovations made by the teaching materials which were originally in the form of text converted into videos, so that students could repeat the material being taught. The teacher takes an interactive approach in implementing teaching materials, so that students remain active during the learning process. The conclusion in this study is that innovative teaching materials are very important to be applied by teachers in the online learning process, so that there are changes in the cognitive, affective and psychomotor aspects of students.
\end{abstract}

Keywords: Civic education, Online Learning, Teaching Materials.

\section{INTRODUCTION}

The problem of the Covid-19 pandemic which has an impact on all aspects of life makes social activities undergo changes. Not with the exception of the education aspect, the entire educational process, which was initially carried out face-to-face, must conform to the health protocol, namely online education [1]. This condition raises challenges in terms of teaching materials, so it is necessary to review the process of learning activities that use teaching materials in the classroom.

In that condition, human existence is threatened by Covid-19 which has an impact on human social activities [2]. In the realm of health, hospitals are experiencing an increase in the number of patients due to hospital unpreparedness which has led to worsening emergency care. This disease is very fast spreading, it can cause a person to develop this disease by interacting at close range and interacting with the sufferer. Therefore, health care providers recommend social distancing, physical distancing, and staying home. This condition can be responded to because the spread of this epidemic continues to various locations in various countries which has pressured many governments in various countries to take steps such as enforcement of quarantine, social restrictions, instructions to stay at home, closure of workplaces, closure of factories and institutions. education [3]. This shows that it is important to plan jobs using strict health guidelines to carry out work regularly.

The conditions of the Covid-19 pandemic make learning must be done online. This was done to reduce the protection of mass body contact so that the chain of virus transmission could be stopped [4]. The government has introduced a strategy to conduct remote teaching and learning activities on an online (network) platform using a mobile phone, PC or laptop to fulfill the learning activities that must be carried out in this academic year. One solution to preventing Covid-19 in the world of education is through online education [5].

Health problems caused by the spread of Covid19 have pioneered schools to simultaneously conduct online learning. The presence of the Covid-19 pandemic has become a variety of obstacles or challenges, 
especially in educational institutions, namely teachers and students carrying out learning at home [6]. The spread of Covid-19 urges e-learning, which is almost never carried out simultaneously by all elements of education, including students, time, location and distance is a big challenge today in the midst of a pandemic, but distance learning is a way to solve educational problems in times of pandemic, as an effort to deal with while defending the classroom even when schools are closed [7].

Teachers and students carried out online learning during the Covid-19 pandemic, directed by the Minister of Education and Culture. In addition, the government makes learning instructions in the context of Distance Learning (PJJ) and working from home. A circular corresponds to this introduction to online learning. On March 17, 2020, the Minister of Education and Culture released a circular on the application of online learning to prevent the corona virus [8]. Internet learning is an alternative during a pandemic, so learning can also be done. Furthermore, to limit the students' travel, online learning was carried out.

During the Covid-19 pandemic, schools must continue to carry out learning to students at home [9]. Learning activities are guided by the teacher online through social media or available learning applications. While carrying out official duties at home / residence, teachers must still achieve performance targets in accordance with the provisions of laws and regulations concerning employee discipline [10]. The extension of the Covid-19 emergency period has increased the learning time from home for students. The consequence is that teachers need to design distance learning that is varied and not boring [11]. Teachers can also provide materials related to Covid-19 to educate students about the dangers of Covid-19, symptoms of infection, and ways to prevent it, besides that teachers can take advantage of several available learning applications, so that distance learning can take place effectively.

Current technological developments have occurred in various sectors, including in the field of education [12]. Among them, such as technology in teaching and learning activities, teachers are not fixated on offline learning but have also been accompanied by online learning. In previous learning activities the teacher only conducted lecture sessions, where the teacher delivered material to students and then added with a question-and-answer session. Such learning models are still very conventional in the midst of current technological developments. Therefore, teachers should be able to develop learning technology in accordance with current developments [13].

In current technological developments, one of the facilities to meet learning needs is in the form of teaching materials that can contain text and media completely, which can be found in the form of e-learning teaching materials as learning materials in general consisting of knowledge, skills, and attitudes students must learn in order to achieve predetermined competency standards. E-learning teaching materials are also known as internet or web-based teaching materials [14]. In addition, e-learning teaching materials are also referred to as online teaching materials. This is because the characteristics of these teaching materials can only be used online [15].

The problem regarding the development of teaching materials is that not all areas have computers, electricity, internet facilities, teachers are required to know learning techniques that use information and communication technology, the tendency to ignore academic or social aspects and the lack of face-to-face interaction between teachers and students even among students themselves [16]. This lack of interaction can slow down the formation of values in the teaching and learning process. This condition indicates the need for the development of teaching materials that are more attractive, effective and efficient to use during the online learning process, so that the development of students' knowledge, attitudes and skills is optimal [17].

To understand the material conveyed by the teacher correctly, learning today requires students to be active. The learning method must take place in a way that is attractive, encouraging, fun, demanding, empowering students to be actively involved, as explained by Winaya, Suarjana \& Mahadewi [18] providing sufficient space for initiative, imagination and adequate freedom. For the skills and desires of students. Based on this, teachers must always be able to train students for initiative, creativity and independence. This is supported by the use of curriculum templates that make it easier for students to understand the learning experience in training.

\section{THEORETICAL REVIEW}

\subsection{Connectivism Theory}

The theory of connectivism in online learning shows that the learning process cannot rely only on teachers [19], so there is a need for a system that is able to accommodate learning properly, effectively and efficiently. During the Covid-19 pandemic, online learning is closely related to the system, so there is a need for teaching materials that can be a source of learning that can be understood by students [20]. In accordance with Siemens' explanation, the theory of connectivism is a theory which explains that the learning process is closely related to the connectivity between matter and reality that occurs in the social sphere. In an effort to provide high learning performance, the e-learning framework must be able to adapt its appearance to a variety of different consumer characteristics [21].

1. Integrity between Goals and Curriculum In the current development of education, learning objectives are expressed in units of core competencies and more precisely, in several metrics. Clear, concrete, achievable, implementable and timely concepts are the basis 
for gathering essential competencies and indicators. In the learning process, you must adjust to the development of image capture technology, especially in camera technology. The previous curriculum, for example, did not involve media that were visual images or in the form of videos as learning material, but were integrated into a discussion of practical hours with the new curriculum.

2. Activities and Assessments

In online learning there are learning tasks for students. In line with Connectivism theory, a model is created which in principle produces a learning network so that a personal learning network is formed. The appraisal tasks in this production are presented from the photographic work and analyzed during the curation phase.

3. Learning materials

The substance of this material is based on learning content, in addition, to find out what information subject participants want to hear about phenomena, the substance is often focused on polls conducted on test subjects or students. The content of this teaching material is intended to adapt the standard content of this teaching material to the needs of students at the diagnostic level requirements [22].

4. Learning Activities

The learning process that occurs in the connectivism model has the following characteristics [23]:

1) Distribution of knowledge through networks (internet)

2) Explore the knowledge trail

3) The foundation of thinking in extracted sources

4) Easy adaptation of learning styles in each network

5) Facilitated knowledge transfer in networks

The origin of learning inspiration is connectivity and relationship management in the sense of social learning networks [24]. What is achieved first in the Connectivism curriculum paradigm is not explicitly on the key points of learning practice, but what it does is train them to learn. Two aspects include the arrangements made. Prepare interest and enthusiasm for learning and prepare to take advantage of the tools used.

\subsection{E-Learning}

Sofyana and Rozaq [25] offer successful ways of learning, such as training with similar input, integrating team practice with individual learning, personalizing learning centred on learner preferences, and using simulations and games. This has led to improvements and advances in various fields, especially in the field of education, through advances in information and communication technology. The role of science and communication technology in education is very important and will facilitate the learning stages of teachers and students. This online learning can be achieved widely and by limitless testing.

Moore, Dickson-Deane, \& Galyen [26] stated that online learning is learning that utilizes accessibility, networking, communication, and resources through internet network learning to develop different types of engagement. Zhang et al. [27] conducted research using the internet and multimedia technology that would change the way knowledge is conveyed as a reaction to tradition.

Online learning is learning that is carried out in the context of the internet and other supporting sources such as cell phones and computers over a considerable distance from the media. According to Riyana [28], online learning shows the thoroughness and caution of students in obtaining and analysing online material which is quite different from learning in general.

\subsection{Teaching Materials}

The success of the learning process is determined by many factors. Teaching materials are an important factor in addition to the factors of educators, students, facilities, and other components. The interaction between these components is very important in achieving the learning objectives designed by the teacher. Good teaching materials will be able to motivate students to study even harder and be able to develop the potential of students.

Teaching materials are all forms of material used to assist teachers / instructors in carrying out teaching and learning activities in the classroom. The material in question can be written or unwritten material [29]. Teaching materials can also be interpreted as information, tools or texts that are needed or used by teachers to plan and examine the implementation of learning. Meanwhile, Prastowo [30] teaching materials are all forms of materials used to assist teachers or instructors in carrying out the learning process in the classroom. The material in question can be written or unwritten material.

Teaching materials are designed in such a way as to pay attention to the type, scope, sequence and treatment. The type of learning material also needs to be identified appropriately. Because each type of teaching material requires different media, evaluation techniques, methods. The depth of the material or scope needs to be considered so that the material is neither less nor more. The order of teaching materials must also be considered so that the learning process is coherent. In addition, the treatment of teaching materials needs to be chosen appropriately so that teaching materials can be identified (what materials need to be memorized, understood, and applied). This is necessary so that a teacher is not mistaken in delivering the teaching material to students. 


\subsection{Citizenship Education}

The meaning of civic education was explained by Ubaedillah and Rozak [31] studying politics and democracy with regard to the responsibilities, duties and privileges of citizens. From these differences of opinion, it is concluded that Civics are a topic that concentrates on community development which, as required by Pancasila and the 1945 Constitution, recognizes and is willing to fulfill its rights and obligations.

Cholisin [32] said that Civics were a teaching tool that deliberately, intelligently and with absolute accountability, Indonesianized students. Therefore, the Civics class includes the basic principles of state administration, politics and state law, as well as other general ideas that are in line with these objectives [33].

In contrast to the above, civic education is seen as training young people to become citizens with the knowledge, credentials and values they need to engage effectively in their society [34].

\section{METHODS}

In this analysis the researcher uses qualitative methods that focus on the problems posed by the researcher. The use of case studies in this research is because case studies are unique, namely this research method focuses on examining in depth the problem aspects, in this study the focus is on the civic education teaching material strategies used during the online learning process during the Covid-19 pandemic.

Participants in this study were teachers, students, and vice principal at 18 Bandung City Senior High School and 15 Bandung City Vocational High School, as well as parents who have an important role, namely as a guide for students while studying at home. The reason for taking the location of the research is because there are differences in the curriculum, namely Senior High Schools and Vocational High Schools, so it is very important to research regarding the use of civic education teaching materials during online learning during the Covid-19 pandemic.

The data collection mechanism is a data collection method or framework that researchers can use. In this study, researchers used interviews, documentation and observation. researchers used the Miles and Huberman Model. Data analysis activities in the Miles and Huberman model include data reduction, display data, and conclusion drawing / verification.

\section{RESULT AND DISCUSSION}

\subsection{Teaching Materials Used by Schools}

Based on the findings of the study, it shows that the teaching materials used by schools show variations that are intended for students to be able to receive the material well. The teaching materials used are compiled from materials that have been collected and come from various learning sources which are systematically made [35]. Based on the research findings, it shows that the considerations in using teaching materials include the following elements:

1. Learning instructions, this component includes instructions for both educators and students. In it, it explains how educators should teach the material to students and how students should learn the material in the teaching material.

2. The competencies that will be achieved, in teaching materials should include competency standards, basic competencies, as well as indicators of achievement of learning outcomes that must be mastered by students. Thus, it is clear the goals that must be achieved by students.

3. Supporting information, is a variety of additional information that can complement a teaching material. It is hoped that students will find it easier to master the knowledge they will acquire. Copy it, the knowledge that learners will gain will be more comprehensive.

4. Exercises, is a form of assignment given to students to practice their abilities after studying teaching materials. Thus, the skills they learn will be more mature and mastered.

5. Work instructions or worksheets, are sheets that contain a number of procedural steps on how to carry out certain activities carried out by students related to practice or others.

6. Evaluation, is one part of the assessment process. Because, in the evaluation component, there are a number of questions addressed to students to measure how far they have mastered the competencies they have successfully mastered after participating in the learning process.

The consideration of teaching materials is also based on their use of technology, so that the teaching materials used are adjusted to the state of technology in schools. Theoretically, teaching materials based on how they work can be divided into five types, namely nonprojected teaching materials, projected teaching materials, audio teaching materials, video teaching materials, and computer teaching materials. Based on the research findings, schools use more projected teaching materials, namely teaching materials that use a projector device so that students can learn or use it and video teaching materials, namely teaching materials that use a player which is usually in the form of a VCD player, DVD player, and etc. This teaching material is almost similar to audio teaching material, because it requires recording media. It's just that the video teaching material is also equipped with pictures. So that in the display there is an image and sound presentation simultaneously.

\subsection{Development of Teaching Materials}

Based on the research findings, it shows that the development of teaching materials is carried out by the Vice Principal in the field of curriculum and also by teachers so that students are able to understand the 
material well. Theoretically, the Ministry of National Education [36] states that teaching materials are a set of materials arranged systematically that allow students to learn and be adapted to the existing curriculum. Sungkono, et al. [37] teaching materials are a set of materials that contain learning material or content to achieve learning objectives. A teaching material contains material or lesson content in the form of ideas, facts, concepts, principles, rules, or theories that cover subjects according to the discipline of knowledge and other information in learning.

Teaching materials can be arranged in such a way as to be more attractive so that students feel happier so that it is easier to learn the material. Lestari [38] the development of teaching materials is based on the concept of learning design based on a competency or to achieve learning objectives. Based on the research findings, it shows that the development of teaching materials carried out by schools follows the view of the Ministry of National Education [39] that in the development of teaching materials, learning principles should be considered, namely:

1. Starting from the easy to understand the difficult, from the concrete to the difficult.

2. Repetition will strengthen understanding.

3. Positive feedback will provide reinforcement for student understanding.

4. High motivation is one of the determining factors for successful learning.

5. Reaching a goal is like climbing a ladder, step by step, eventually reaching a certain height.

6. Knowing the results that have been achieved will encourage students to continue to achieve goals.

7. Some things that must be considered in making teaching materials that are able to make students learn independently and get completeness in the learning process are as follows:

8. Contains interesting examples and illustrations in order to support the presentation of learning materials.

9. Provides the possibility for students to provide feedback or measure their mastery of the material provided by providing practice assignment questions, and the like.

10. Contextual, namely the material presented in relation to the atmosphere or context of the assignment and the student's environment.

11. The language used is quite simple because students only deal with teaching materials when learning independently [40].

In this case, the development of teaching materials is a series of processes carried out to produce teaching materials that can provide interesting examples from easy to difficult ones in stages, provide feedback, motivate, and know the results that have been achieved.

\subsection{Successful Implementation of Teaching Materials Development}

Based on the research findings, it shows that the development of teaching materials in schools has an impact on students' ability to understand the material. This indicates that there is the effectiveness of the learning method which is a measure related to the success rate of a learning process [41]. Theoretically, effectiveness can be measured by looking at students' interest in learning activities. If students are not interested in learning something, it cannot be expected that they will do well in learning the subject matter. Conversely, if students learn according to their interests, it can be expected that the results will be better.

The success of developing teaching materials is a measure related to the success rate of a learning process. The criteria for the success of teaching materials in schools refer to:

1. Completeness of learning, learning can be said to be complete if at least $75 \%$ of the total number of students has obtained a value of $=60$ in improving learning outcomes.

2. The learning model is said to be effective in improving student learning outcomes if statistically students' learning outcomes show a significant difference between initial understanding and post-learning understanding (significant gain).

3. The learning model is said to be effective if it can increase interest and motivation if after learning students become more motivated to study harder and obtain better learning outcomes. As well as students learn in pleasant conditions.

Completeness of learning is defined as an approach to learning that requires students to completely master all competency standards, basic competencies and predetermined indicators. Completeness of learning can be seen individually or in groups.

Based on the observations of researchers, there are factors that determine the success of developing teaching materials in schools, namely:

1. Objective Factor

The end result of a learning process that becomes the set learning objectives is change. Changes in thought patterns, changes in feelings, and also changes in behavior patterns or behaviorism. The changes that occur are the indicators of the success of students in the learning process. This is the real purpose of learning.

2. Learner Factors

Subjective and objective data as well as nominations about students obtained through the identification process, and differences in individual types in terms of responding to something or how individuals get responses 
about something. There are three individual types of students in terms of responding to something, namely the visual type, auditive type, and motoric type. For visual types, students who have this type are easier to get responses about something through their sense of sight.

3. Situation Factors

Talk content about learning situations is often more on concrete conditions and their effects on the learning process. The content or content of the conversation about learning situation factors other than hot or cold weather, noisy, rush, and situations of inappropriate space or facilities are also related to the heart and inner situation of the teachers or educators while teaching and also the heart and inner situation of students when the learning process takes place. Because the situation itself is something that can be formed / created and can be controlled, a teacher should have the ability to create that situation and also have the managerial ability to regulate and control the situation itself.

4. Teacher Factors

There are two important characteristics that must be demonstrated by a professional teacher during the learning process and also outside the learning process. The two characteristics of professional teachers are proficient in combining various teaching methods and are able to play various teacher roles in various situations and in various needs of students [42].

\section{CONCLUSION}

The development of teaching materials is a very important activity in adapting to online learning, because teaching materials in normal times have shortcomings when applied by online teachers. The success of curriculum development carried out at 18 Bandung City Senior High Schools and 15 Bandung City Vocational High Schools is due to the support from internal schools, student enthusiasm for learning and the ability of teachers who are proficient in using technology. This makes the development of teaching materials have an impact on the abilities of students

\section{REFERENCES}

[1] Y.K.D. Dwivedi, L. Hughes, C. Coombs, I. Constantiou, Y. Duan, J.S. Edwards, B. Gupta et al. "Impact of COVID-19 pandemic on information management research and practice: Transforming education, work and life." International Journal of Information Management 55 (2020): 102211.

[2] S.J. Barnes, "Information management research and practice in the post-COVID-19 world." International Journal of Information Management 55 (2020): 102175.
[3] H.S. Munawar, S.I.Khan, Z. Qadir, A.Z. Kouzani, and M.A. Mahmud. "Insight into the Impact of COVID-19 on Australian Transportation Sector: An Economic and Community-Based Perspective." Sustainability 13, no. 3 (2021): 1276.

[4] J.G. Adams and R.M. Walls. "Supporting the health care workforce during the COVID-19 global epidemic." Jama 323, no. 15 (2020): 1439-1440.

[5] H. Ramdhani. "Politik Kewarganegaraan berbasis Nilai-Nilai Pancasila Dimasa Pandemi Covid-19." Jurnal Pendidikan Sosial Keberagaman 7, no. 2 (2020), 117-124.

[6] C. Rapanta, L. Botturi, P. Goodyear, L. Guàrdia, and M. Koole. "Online university teaching during and after the Covid-19 crisis: Refocusing teacher presence and learning activity." Postdigital Science and Education 2, no. 3 (2020): 923-945.

[7] R.S. Putri, A. Purwanto, R. Pramono, M. Asbari, L.M. Wijayanti, and C.C. Hyun. "Impact of the COVID-19 pandemic on online home learning: An explorative study of primary schools in Indonesia." International Journal of Advanced Science and Technology 29, no. 5 (2020): 4809-4818.

[8] Kemdikbud. (2020). SE Mendikbud: Pembelajaran secara daring dan bekerja dari rumah untuk mencegah penyebaran covid-19 .Diakses tanggal 2 April 2020 dari https:/www.kemdikbud.go.id/main/blog/2020/03/s e-mendikbud-pembelajaran-secara-daring-danbekerja-dari-rumah-untuk-mencegah-penyebarancovid19.

[9] M. Suryaman, Y. Cahyono, D. Muliansyah, O. Bustani, P. Suryani, M. Fahlevi, R. Pramono, A. Purwanto, J.T. Purba, and A.P. Munthe. "COVID-19 pandemic and home online learning system: Does it affect the quality of pharmacy school learning?." Syst. Rev. Pharm 11 (2020): 524-530.

[10] I. Thaief, and A. Baharuddin. "Effect of training, compensation and work discipline against employee job performance." Rev. Eur. Stud. 7 (2015): 23.

[11] K. Venter. "Coping with isolation: The role of culture in adult distance learners' use of surrogates." Open Learning: The Journal of Open, Distance and e-Learning 18, no. 3 (2003): 271-287.

[12] J. Martín-Gutiérrez, C.E. Mora, B. Añorbe-Díaz, and A. González-Marrero. "Virtual technologies trends in education." EURASIA Journal of Mathematics, Science and Technology Education 13, no. 2 (2017): 469-486.

[13] A. Bray, and B. Tangney. "Technology usage in mathematics education research-A systematic review of recent trends." Computers \& Education 114 (2017): 255-273.

[14] K.H Lau, T. Lam, B.H. Kam, M. Nkhoma, J. Richardson, and S. Thomas. "The role of textbook 
learning resources in e-learning: A taxonomic study." Computers \& Education 118 (2018): 10-24.

[15] M.S. Taat, and A. Francis. "Factors Influencing the Students' Acceptance of E-Learning at Teacher Education Institute: An Exploratory Study in Malaysia." International Journal of Higher Education 9, no. 1 (2020): 133-141.

[16] L.D.S.Lapitan Jr, C.E. Tiangco, D.A.G. Sumalinog, N.S. Sabarillo, and J.M. Diaz. "An effective blended online teaching and learning strategy during the COVID-19 pandemic." Education for Chemical Engineers 35 (2021): 116-131.

[17] X. Wei, L. Lin, N. Meng, W. Tan, and S.C. Kong. "The effectiveness of partial pair programming on elementary school students' computational thinking skills and self-efficacy." Computers \& Education 160 (2021): 104023.

[18] I.K. Winaya, I.M. Suarjana, \& L.P.P. Mahadewi, Analisis Rencana Pelaksanaan Pembelajaran Menurut Kurikulum 2013 Kelas IV SD No. 4 Banyuasri. MIMBAR PGSD Undiksha, 3(1), 2015, $1-12$.

[19] N.N. Pokrovskaia, V.L. Leontyeva, M.Y. Ababkova, L. Cappelli, and F. D'Ascenzo. "Digital Communication Tools and Knowledge Creation Processes for Enriched Intellectual OutcomeExperience of Short-Term E-Learning Courses during Pandemic." Future Internet 13, no. 2 (2021): 43.

[20] R.R. Aliyyah, R. Rachmadtullah, A. Samsudin, E. Syaodih, M. Nurtanto, and A.R.S. Tambunan. "The perceptions of primary school teachers of online learning during the COVID-19 pandemic period: A case study in Indonesia." Journal of Ethnic and Cultural Studies 7, no. 2 (2020): 90-109.

[21] P.S. Siyamta, W. Kamdi, \& S. Ulfa, Teori Connectivism Dalam Pembelajaran Sebagai Pendukung Sistem Adaptive E-Learning and Big Data Personalized Learning. [online]. Diakses dari http://digilib.mercubuana.ac.id/manager/t!@file_art ikel_abstrak/Isi_Artikel_411053189890.pdf

[22] F. Inan \& M. Grant. Individualized web-based instructional design. In Instructional Design: Concepts, Methodologies, Tools and Applications IGI Global, 2011, 375-388.

[23] M.E. Del Moral, A. Cernea \& L. Villalustre, Connectivist learning objects and learning styles. Interdisciplinary Journal of E-Learning and Learning Objects, 9(1), 2013, 105-124.

[24] C. Dwyer, S. Hiltz, \& K. Passerini, Trust and privacy concern within social networking sites: A comparison of Facebook and MySpace. AMCIS 2007 proceedings, 2007, 339.

[25] L. Sofyana, \& A. Rozaq, Pembelajaran Daring Kombinasi Berbasis Whatsapp Pada Kelas Karyawan Prodi Teknik Informatika Universitas
Pgri Madiun. Jurnal Nasional Pendidikan Teknik Informatika: JANAPATI, 8(1), 2019, 81-86.

[26] J.L. Moore, C. Dickson-Deane \& K. Galyen, eLearning, online learning, and distance learning environments: Are they the same?. The Internet and Higher Education, 14(2), 2011, 129-135.

[27] J.L.D. Zhang, Zhao, L. Zhou \& F.N. Jay, F. N, Can e-learning replace classroom learning. Commun. ACM, 47(5), 2014, 75-79.

[28] C. Riyana, Developing Mobile Learning Management System (Mlms) Based on Android For Curriculum Literacy. Edulib, 8(2), 2018, 222-239.

[29] A. Mudlofar, Aplikasi Pengembangan Kurikulum Tingkat Satuan Pendidikan dan Bahan Ajar dalam Pendidikan Islam. Jakarta: Rajawali Pers, 2012.

[30] A. Prastowo, Panduan Kreatif Membuat Bahan Ajar Inovatif. Yogyakarta: Diva Press, 2012.

[31] A. Ubaedillah, \& A. Rozak, Pendidikan Kewargaan (Civic Education) Demokrasi Hak Asasi Manusia dan Masyarakat Madani. Jakarta: ICCE UIN JakartaKencana, 2011.

[32] C. Cholisin, Reorientasi dan Rekonstruksi Paradigma Lama Pendidikan Kewarganegaraan Menuju Indonesia Bard. Cakrawala Pendidikan, 2000.

[33] R. Rachmadtullah \& P.A. Wardani, Peningkatan Hasil Belajar Pendidikan Kewarganegaraan Melalui Metode Pembelajaran Contexstual and Learning. Jurnal Pendidikan Dasar, 7(1), 2016, 116-127.

[34] G.P. Mulyoto, \& S. Samsuri, Pengaruh model project citizen dengan pendekatan saintifik terhadap penguasaan kompetensi kewarganegaraan dalam pembelajaran Pendidikan Pancasila dan Kewarganegaraan. Jurnal Civics: Media Kajian Kewarganegaraan, 14(1), 2017, 105-118.

[35] Op.cit, Prastowo (2012).

[36] Depdiknas (2006). Kurikulum 2006. Jakarta: Depdiknas.

[37] S. Sungkono, Pengembangan dan Pemanfaatan Bahan Ajar Modul dalam Proses Pembelajaran. Majalah Ilmiah Pembelajaran, 5(1), 20009, 1-13.

[38] I. Lestari, Pengembangan bahan ajar berbasis kompetensi. Padang: Akademia Permata, 2013.

[39] Op.cit, Depdiknas (2006).

[40] C. Widodo and Jasmadi. Buku Panduan Menyusun Bahan Ajar. Jakarta: PT Elex Media Komputindo, 2008.

[41] H. Hikmat, E. Hermawan, A. Aldim, \& I. Irwandi, Efektivitas pembelajaran daring selama masa pandemi Covid-19: Sebuah survey online. LP2M, 2020.

[42] I.T. Ratu, Sumber Kecerdasan Manusia. Jakarta: PT. Grasindo, 2016 